\title{
Optimization of the Management of an Ex-situ Germplasm Bank in Common Fig with SSRs
}

\author{
Esther Giraldo and Margarita Lopez-Corrales \\ Department of Hortofruticulture, Servicio de Investigación y Tecnología, \\ Finca La Orden-Valdesequera, 06187 Guadajira, Badajoz, Spain \\ Jose Ignacio Hormaza ${ }^{1}$ \\ Estación Experimental la Mayora, CSIC, 29750 Algarrobo-Costa, Málaga, Spain
}

\begin{abstract}
AdDitional INDEX words. Ficus carica, genetic diversity, genetic resources, microsatellites, molecular markers, Moraceae
Abstract. Common fig (Ficus carica L.) is an underused fruit crop cultivated in Mediterranean countries since antiquity. In this study, 20 simple sequence repeat (SSR) loci were used to characterize 209 fig accessions conserved in an ex-situ field germplasm collection. A total of 78 fragments were amplified with the 20 pairs of SSR primers, with an average of 3.9 alleles per locus and a size between 120 and $376 \mathrm{bp}$. The mean expected and observed heterozygosities were 0.36 and 0.41 , respectively. The total value for the probability of identity was $6.8 \times 10^{-4}$. The SSRs studied resulted in identification of 98 unique genotypes $(46.86 \%$ of all accessions preserved in the bank), indicating a high number of synonyms. Unweighted pair group method with arithmetic averages (UPGMA) cluster analysis did not show clear groups based on geographic distance, although some specific groups related to fruit type were observed. The results confirm the usefulness of microsatellites for the identification of genetic diversity and potential value of germplasm management for fig.
\end{abstract}

Common fig $(2 n=26)$ belongs to the Moraceae, a family with $>1400$ species classified into $\approx 40$ genera (Watson and Dallwitz, 2004). The genus Ficus L. contains $\approx 700$ species, mainly in the tropics, currently divided into six subgenera (Berg, 2003). Common fig is considered, together with grape (Vitis vinifera L.) and olive (Olea europaea L.), one of the three classical fruit trees associated with the beginning of horticulture in the Mediterranean Basin (Zohary and Spiegel-Roy, 1975), and consequently it is one of the earliest domesticated fruit tree species (Janick, 2005; Khadari et al., 2005; Zohary and Hopf, 2000). In fact, recent studies (Kislev et al., 2006) indicate that common fig is probably the first domesticated crop of the Neolithic revolution. Fig cultivation has extended throughout other regions of the world with mild weather. Current total world fig production has reached $>1$ million tonnes, with a few countries (Turkey, Egypt, Greece, Iran, Morocco, Spain, and the United States) accounting for $\approx 70 \%$ of the production, with Turkey being the main producer with $\approx 25 \%$ of the world production (Food and Agricultural Organization of the United Nations, 2005).

Common fig is a gynodioecious species with two different morphs: female trees that produce syconia with female flowers that will develop into edible seeded figs (syconia with multiple one-seed fruit or drupelets) and caprifigs that produce syconia with male and female flowers with a shorter style than female flowers of female trees. Because only caprifigs produce pollen, the reproductive system is functionally dioecious (Kjellberg et al., 1987). Three types of female figs are grown commercially (Storey, 1976): common type that develops fruit parthenocarpically, the Smyrna type that requires pollination with pollen from caprifigs (caprification) to develop fruit, and the San Pedro

Received for publication 7 May 2007. Accepted for publication 14 Sept. 2007. Financial support for this work was provided by the Spanish Ministry of Education (Project Grants AGL2001-2414-C04 and AGL2004-02290/AGR).

${ }^{1}$ Corresponding author. E-mail: ihormaza@eelm.csic.es. type that produces a first crop (brevas) parthenocarpically and a second crop (fig) only after pollination. Common-type figs can produce one (unifera types) or two crops (bifera types).

The long history of fig cultivation has resulted in hundreds of cultivars available worldwide, and consequently, appropriate germplasm characterization and diversity studies are very valuable for efficient management of fig genetic resources. Synonyms and homonyms are especially common in vegetatively propagated fruit tree species, such as fig, for which the cost of maintaining unwanted duplicate genotypes in ex-situ germplasm collections can be a limiting factor. Fig cultivar identification has been usually carried out using traditional methods based on phenotypic traits [International Plant Genetics Resources Institute (IPGRI) and International Center for Advanced Mediterranean Studies (CIHEAM), 2003]. As an example, Condit (1955) described >600 cultivars of fig. However, traditional characterization using morphologic and agronomic parameters is expensive and often ineffective in distinguishing genotypes due to the influence of the environment, the limited number of discriminating traits, and the need to study a high number of characters in organs that are not always present. Therefore, recently, as with other fruit tree species (Wünsch and Hormaza, 2002), molecular identification of fig cultivars has been carried out with different molecular systems, such as isozymes (Cabrita et al., 2001; Chessa et al., 1998; Elisario et al., 1998), RAPDs (Cabrita et al., 2001; Chessa and Nieddu, 2005; De Masi et al., 2005; Galderisi et al., 1999; Khadari et al., 1995; Papadopoulou et al., 2002; Salhi-Hannachi et al., 2005; Sadder and Ateyyeh, 2006), AFLPs (Cabrita et al., 2001), or ISSRs (Khadari et al., 2004; Salhi-Hannachi et al., 2004, 2005). However, microsatellites or SSR (SSRs) have become the markers of choice for fingerprinting and analysis of genetic diversity in most plant species (Gupta and Varshney, 2000) due to their high level of polymorphism, codominant Mendelian inheritance, reproducibility, and easy detection through PCR and electrophoretic methods. 
Until recently, the use of SSR markers has been limited due to the high costs associated with the construction and screening of genomic libraries to find sequences flanking the repeated regions. However, the development of genomic libraries enriched with SSRs sequences has allowed the use of these markers on a larger scale. Thus, $>50$ microsatellites have been recently isolated and characterized in fig (Giraldo et al., 2005; Khadari et al., 2001), and some of them have been used to identify fig genotypes (Giraldo et al., 2005; Khadari et al., 2004).

The objective of this work is to use the SSRs developed in fig to fingerprint and study the genetic similarity among 209 genotypes conserved in the Spanish fig germplasm bank located in Badajoz.

\section{Materials and Methods}

Plant material. Two-hundred nine fig accessions from diverse geographical areas maintained at the Finca La Orden of the Junta de Extremadura, Badajoz, Spain, were analyzed in this study. Among those accessions, 196 were collected from different regions in Spain and 13 were obtained from other countries (Table 1).

Genomic DNA extraction AND PCR amplification. Genomic DNA extraction was performed on dormant winter buds following the protocol described in Giraldo et al. (2005). The DNA was quantified spectrophotometrically and diluted to $10 \mathrm{ng} \cdot \mu \mathrm{L}^{-1}$ in modified TE buffer $(10 \mathrm{~mm}$ Tris- $\mathrm{HCl}, 0.1 \mathrm{~mm}$ EDTA). The extracted DNA was amplified by PCR, using 20 pairs of microsatellite primers (Table 2), 16 developed by Giraldo et al. (2005) and four by Khadari et al. (2001). These SSRs were chosen due to the high quality of amplification and reproducibility of the results. PCR reactions were performed in an iCycler (Bio-Rad Laboratories, Hercules, CA) as reported by Giraldo et al. (2005). Size evaluation of the amplified fragments was performed using a CEQ 8000 capillary DNA analysis system (Beckman Coulter, Fullerton, CA). Reverse primers of each primer pair were labeled with WellRED fluorescent dyes D2, D3, and D4 (Proligo, Paris, France). The analyses were repeated at least twice to assure the reproducibility of the results.

DAta ANALYsis. Genetic relationships among the fig accessions were represented by UPGMA cluster analysis of the similarity matrix obtained from the proportion of shared amplification fragments (Nei and Li, 1979). The cophenetic correlation coefficient was estimated by comparing with the Mantel test the cophenetic matrix obtained from the dendrogram with the original similarity matrix. All of these analyses were computed with NTSYSpc 2.11 (Exeter Software, Stauket, NY). Bootstrap support values were obtained from 2000 replicates using TREECON 1.3b (Van de Peer and De Wachter, 1994).

For the SSRs that amplified a single locus, different indices of genetic variability were calculated: number of alleles per locus and accession, observed heterozygosity $\left(H_{\mathrm{o}}\right.$, direct count, calculated as the number of heterozygous genotypes over the total number of genotypes analyzed for each locus), expected heterozygosity $\left(\mathrm{He}=1-\sum p i^{2}\right.$, where $p i$ is the frequency of the $i$ th allele in the cultivar; Nei 1973), effective number of alleles $[\mathrm{Ne}=1 /(1-\mathrm{He})]$, Wright's fixation index $(F=1-\mathrm{Ho} / \mathrm{He})$ (Wright 1951), and the probability of identity $\left[\mathrm{PI}=1-\sum p i^{2}+\right.$ $\sum \sum(2 p i p j)^{2}$, where $p i$ and $p j$ are the frequency of the $i$ th and $j$ th alleles, respectively] that measures the probability of two accessions sharing the same alleles (Paetkau et al., 1995). Total probability of identity, defined as the probability of two cultivars sharing the same genetic profile by chance, was also calculated from individual PI values. All of these parameters were calculated with IDENTITY 1.0 (Wagner and Sefc, 1999) and POPGENE 1.32 (Yeh and Boyle, 1997).

When synonyms were found, the selection of the reference cultivar names was made according to the apparent seniority or frequency of the names used, historical records, or bibliographic references (Condit, 1955; Estelrich, 1910; Priego Jaramillo and Sanchiz, 1934; Rosselló et al., 1996).

\section{Results and Discussion}

SSR POLYMORPHISM AND GENETIC DIVERSITY. The total number of alleles detected with the selected 20 SSRs was 78, ranging between two and nine alleles per locus, with an average of 3.9 alleles per locus and a size between 120 and $376 \mathrm{bp}$. Eight out of the 20 SSRs (LMFC12, LMFC13, LMFC17, LMFC19, LMFC30, LMFC32, MFC1, and MFC4) showed three amplification fragments in some genotypes, and one SSR (LMFC28) produced up to four fragments indicating possible amplification of more than one locus. The remaining 11 SSRs showed one or two bands per genotype, suggesting amplification of a single locus, although fragment segregation in the progeny obtained from a cross is the only way to assign alleles to a particular locus. Consequently, for these 11 loci the accessions studied were considered homozygous or heterozygous when one or two fragments are present per locus, respectively (Callen et al., 1993). For these 11 loci, genetic parameters were computed. Allelic frequencies ranged from 0.0024 to 0.95 , with a mean of 0.33 . A total of $36.4 \%$ of the alleles analyzed were considered rare $(P<0.1)$. Only $9.1 \%$ of the alleles were fixed in most of the genotypes $(P>0.9)$, and seven alleles were each found in only one of the 209 accessions: allele 334 of LMFC19 is present only in 'Smyrna', allele 242 of LMFC24 is present only in accession 176, allele 250 of LMFC30 is present only in accession 179, allele 133 of MFC5 is present only in 'Moisoniere', and three unique alleles are amplified with LMFC32 (223 bp in 'Pezonuda', 217 bp in 'Smyrna', and 211 bp in 'Cordobis'). These rare alleles were verified and validated after two replicates.

Expected heterozygosity ranged from 0.09 in LMFC23 to 0.74 in MFC2 (mean of 0.36) (Table 3). Observed heterozygosity ranged from 0.10 in LMFC23 to 0.80 in MFC2 (mean of 0.41). For all single-locus SSRs except two (LMFC15 and LMFC21), the observed heterozygosity was higher than the expected. Consequently, most of the $F$ values are negative with an average overall single locus SSRs of -0.12 , showing homozygote deficiency. Regarding the probability of identity, the maximum (0.84) was detected in LMFC23 and the minimum (0.20) in MFC2, with a total PI of $6.8 \times 10^{-4}$.

The number of alleles per locus (3.9) and $\mathrm{He}(0.38)$ are relatively low compared with other works in fig with a lower number of genotypes or loci; Khadari et al. (2004) reported an average of 6.2 alleles per locus and an average He of 0.60 with six SSRs and 72 Moroccan fig cultivars. This could reflect a low polymorphism in the accessions studied that could indicate a common origin of cultivated fig in Spain, although further work involving fig cultivars from geographically diverse areas will be needed to address this point. The ease of vegetative propagation in this species and its long history of cultivation, together with the focus on selection of parthenocarpic cultivars 
Table 1. Accessions of reference conserved in the Spanish fig germplasm bank and the synonyms found with 20 SSRs.

\begin{tabular}{|c|c|c|c|}
\hline Accession & Origin & Type & Synonyms in the germplasm bank \\
\hline Albacor $^{z}$ & Balearic Islands & Bifera & $\begin{array}{l}\text { Ademuz, Albacor, Alcacer 1, Bacorera, Betera, Breval Málaga, } \\
\text { Colar Elche, Cuello de Dama Negra, Del Gra Negre, Goen, } \\
\text { Mission, Napolitana Negra Brevera Foyos, Negra, Negra 3, } \\
\text { Negra Común R, Negra Málaga, Negra Tocinera, Torre Baja 1, } \\
\text { 9602, 9603, 9607, } 9616\end{array}$ \\
\hline Albar & Extremadura & Bifera & \\
\hline Angelina & Balearic Islands & Bifera & Algerina \\
\hline Ayuela & Extremadura & Bifera & \\
\hline Bec de Perdiu & Catalonia & Bifera & $\begin{array}{l}\text { Burriana 1, Napolitana Chelva 1, Napolitana, Napolitana Enguera, } \\
\text { Napolitana Negra, Napolitana Negra Foyos, Napolitana Mas } \\
\text { Valero, Negra Pozuelo, Torre Baja 3, Napolitana }\end{array}$ \\
\hline Bermejí & Extremadura & Bifera & \\
\hline Bermesca $^{\mathrm{y}}$ & Balearic Islands & Bifera & Calabacita \\
\hline Blava & Balearic Islands & Bifera & \\
\hline Boja o Farta Belitres & Catalonia & Unifera & \\
\hline Bota Morada & Castile and Leon & Bifera & Serranilla \\
\hline Boyuna & Extremadura & Bifera & Porronta \\
\hline Brocalet $^{\mathrm{x}}$ & Balearic Islands & Unifera & $\begin{array}{l}\text { De Ley 2, Lloral, Martinenca Rimada, Martinenca (Mallorca), } \\
\text { Martinenca Mina, Martinenca (Reus), Porquenya }\end{array}$ \\
\hline Brown Turkey & United States & Bifera & Albatera, Desconegut 12 \\
\hline Burjassot Alguaire & Catalonia & Unifera & \\
\hline Burjassot Blanca & Valencia & Unifera & Albacor, Burjassot V \\
\hline Burjassot Negre & Catalonia & Unifera & Paratjal, Pota de Cavall \\
\hline Burreña & Extremadura & Bifera & \\
\hline Coll de Dama Negrew & Balearic Islands & Unifera & $\begin{array}{l}\text { Breva Q, Coll de Dama Blanca, Coll de Dama Rosa, Cuello de } \\
\text { Dama Negre, Cuello de Dama Rosa, De Lley 1, Ull de Perdiu } \\
\text { Mina, 9603, 9605, } 9615\end{array}$ \\
\hline Coll de Dama Rosa ${ }^{w}$ & Catalonia & Unifera & $\begin{array}{l}\text { Breva Q, Coll de Dama Blanca, Coll de Dama Negre, Cuello de } \\
\text { Dama Negre, Cuello de Dama Rosa, De Lley 1, Ull de Perdiu } \\
\text { Mina, 9603, 9605, } 9615\end{array}$ \\
\hline Conadria & United States & Bifera & \\
\hline Cordobis & Extremadura & Unifera & \\
\hline Cornudella & Catalonia & Unifera & \\
\hline Cucurella & Catalonia & Unifera & De la Gota de Miel, 178, 184 \\
\hline Cuiro de Bou & Balearic Islands & Unifera & \\
\hline De Baco & Catalonia & Bifera & \\
\hline De Butxaca & Catalonia & Bifera & \\
\hline De'n Manel & France & Bifera & Tres voltas L'Any-1 \\
\hline De Rey & Extremadura & Bifera & \\
\hline Desconegut 85 & Catalonia & Bifera & \\
\hline Doña Maria & Extremadura & Bifera & \\
\hline Dottato & Balearic Islands & Bifera & $\begin{array}{l}\text { Blanca Cabezuela, Cuello de Dama Blanco, Del Guardia, Gota de } \\
\text { Miel, Kadota, Napolitana Blanca }\end{array}$ \\
\hline Genyiva Mort & Catalonia & Bifera & \\
\hline Granito & Extremadura & Bifera & \\
\hline Hoñigal & Extremadura & Unifera & \\
\hline
\end{tabular}


Table 1. Continued.

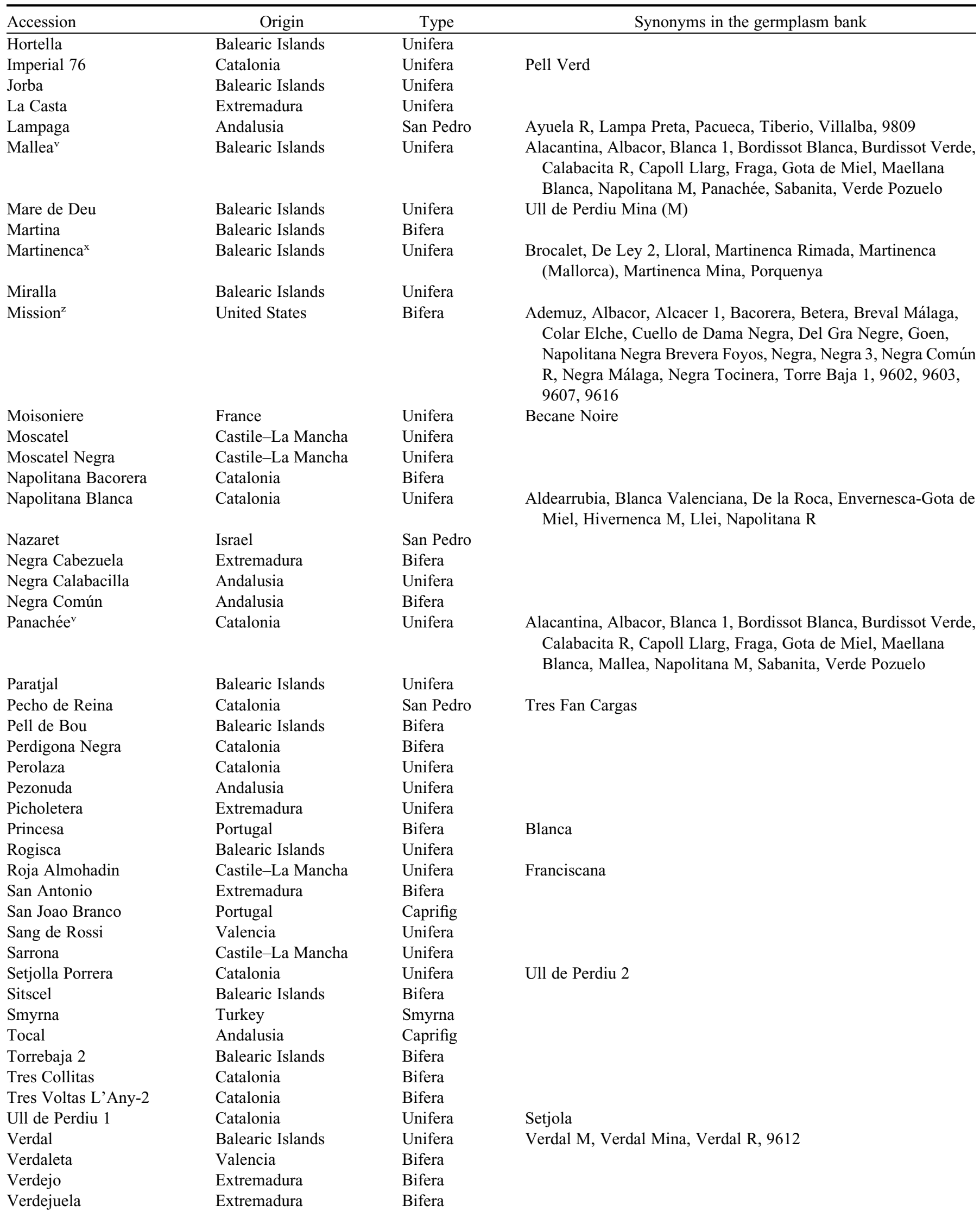


Table 1. Continued.

\begin{tabular}{|c|c|c|c|}
\hline Accession & Origin & Type & Synonyms in the germplasm bank \\
\hline White Genoa & United States & Unifera & \\
\hline Zuguele & Extremadura & Bifera & \\
\hline 120 & France & Bifera & \\
\hline 152 & Catalonia & Bifera & \\
\hline 176 & Catalonia & Unifera & \\
\hline 179 & Catalonia & Unifera & 181 \\
\hline 218 & Catalonia & Unifera & \\
\hline 9606 & Aragon & Unifera & \\
\hline 9608 & Aragon & Unifera & \\
\hline 9611 & Aragon & Bifera & \\
\hline 9614 & Aragon & Unifera & \\
\hline
\end{tabular}

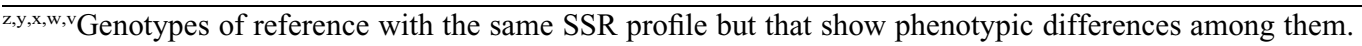

Table 2. Locus name, sequence, repeat motif, GenBank accession number, and literature reference for the 20 polymorphic microsatellites used in the identification of fig cultivars.

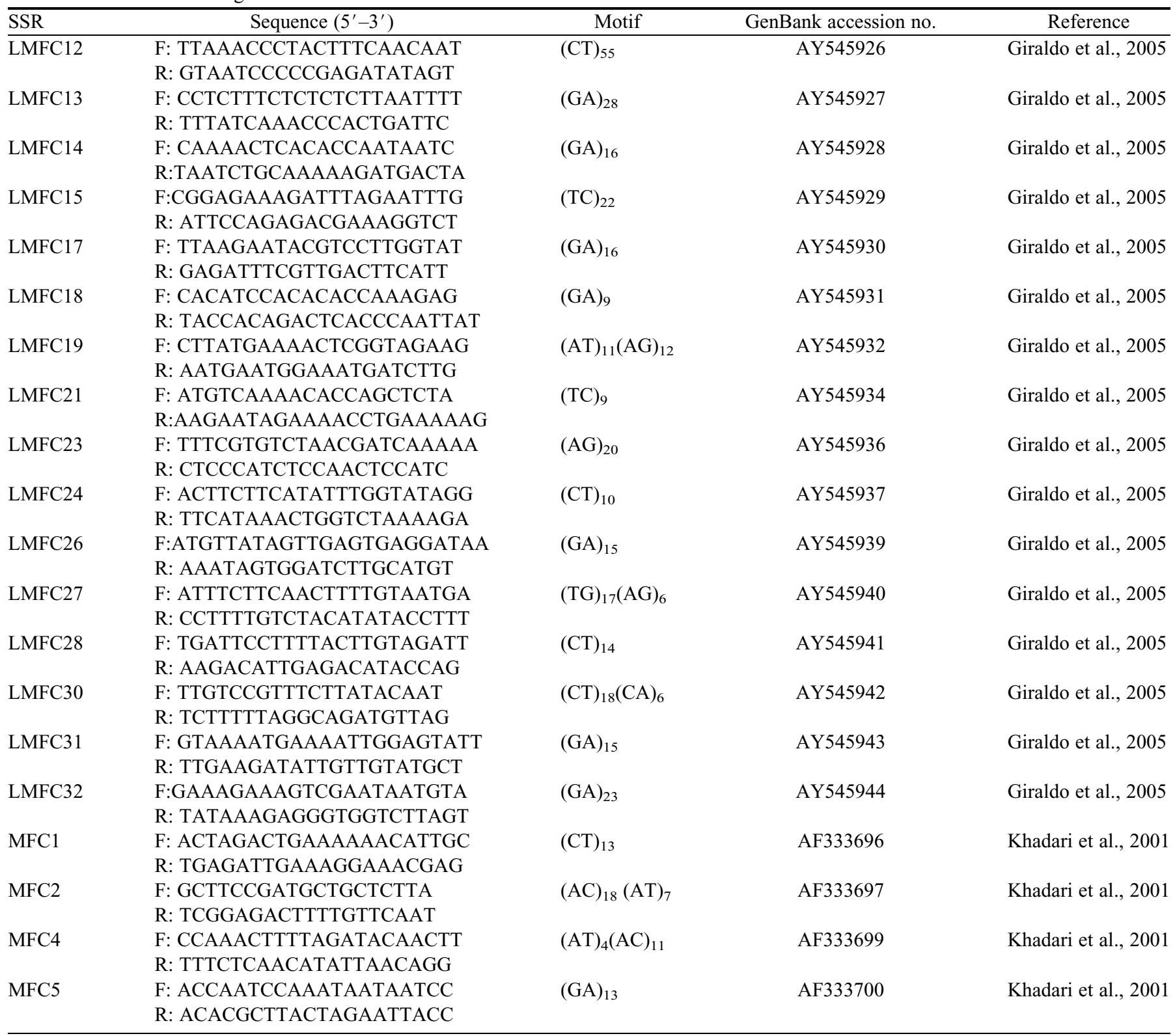


Table 3. Locus name, range size of the amplified fragments, number of alleles (A), observed (Ho) and expected (He) heterozygosities, probability of identity (PI), and Wright's fixation index (F) calculated for 20 SSR markers in 209 fig cultivars.

\begin{tabular}{|c|c|c|c|c|c|c|}
\hline SSR & Size (bp) & A & Но & $\mathrm{He}$ & PI & $\mathrm{F}$ \\
\hline $\mathrm{LMFC}_{12}{ }^{\mathrm{z}}$ & $350-376$ & 3 & & & & \\
\hline $\mathrm{LMFC}_{13}{ }^{\mathrm{z}}$ & $270-298$ & 4 & & & & \\
\hline LMFC14 & $213-215$ & 3 & 0.38 & 0.36 & 0.51 & -0.06 \\
\hline LMFC15 & $183-207$ & 3 & 0.20 & 0.21 & 0.66 & 0.05 \\
\hline $\mathrm{LMFC} 17^{\mathrm{z}}$ & $188-203$ & 4 & & & & \\
\hline LMFC18 & $120-126$ & 2 & 0.41 & 0.37 & 0.60 & -0.11 \\
\hline LMFC $19^{z}$ & 299-334 & 5 & & & & \\
\hline LMFC21 & $265-271$ & 3 & 0.12 & 0.12 & 0.78 & 0.00 \\
\hline LMFC23 & $132-134$ & 2 & 0.10 & 0.09 & 0.84 & -0.11 \\
\hline LMFC24 & $242-278$ & 4 & 0.58 & 0.47 & 0.57 & -0.23 \\
\hline LMFC26 & $224-237$ & 3 & 0.36 & 0.31 & 0.56 & -0.16 \\
\hline LMFC27 & $186-196$ & 2 & 0.59 & 0.47 & 0.61 & -0.26 \\
\hline LMFC28 $8^{z}$ & $183-203$ & 6 & & & & \\
\hline $\mathrm{LMFC} 0^{\mathrm{z}}$ & $231-262$ & 9 & & & & \\
\hline LMFC31 & $228-242$ & 2 & 0.61 & 0.49 & 0.62 & -0.24 \\
\hline $\mathrm{LMFC} 2^{\mathrm{z}}$ & 199-223 & 7 & & & & \\
\hline $\mathrm{MFC}^{\mathrm{z}}$ & $160-192$ & 4 & & & & \\
\hline MFC2 & $157-170$ & 5 & 0.80 & 0.74 & 0.20 & -0.08 \\
\hline $\mathrm{MFC}^{\mathrm{z}}$ & $198-221$ & 3 & & & & \\
\hline MFC5 & $128-142$ & 4 & 0.36 & 0.31 & 0.60 & -0.16 \\
\hline Mean & & 3,9 & 0.41 & 0.36 & 0.60 & -0.12 \\
\hline
\end{tabular}

${ }^{\text {Zndicates amplification of more than two fragments in some }}$ genotypes.

(common type), have allowed the widespread transfer of selected plant stocks among different regions. This could explain the high number of synonyms found in the accessions studied [the 78 polymorphic amplification fragments detected with the 20 SSRs studied allowed the unambiguous identification of only 98 genotypes (46.86\%) of all accessions preserved in the bank] due probably to local naming of clones propagated vegetatively that, in some cases, may show some phenotypic differences due to different local environmental factors. In any case, a low level of polymorphism has been reported in other works in fig with different molecular markers and cultivars even from different countries (Galderisi et al., 1999; Giraldo et al., 2005; Khadari et al., 1995; Papadopoulou et al., 2002).

SELECTION OF REFERENCE Genotypes. Due to the high number of synonyms and homonyms detected in the germplasm bank, a reference cultivar name was chosen within each genetic profile except for five of the 98 groups, where two or three reference cultivars have been selected because clear morphological differences were found; those differences include flesh color, as with 'Albacor' and 'Mission' or 'Coll de Dama Blanca', 'Coll de Dama Negre', and 'Coll de Dama Rosa'; fruit size and shape, as with 'Bermesca' and 'Calabacita,' and 'Brocalet' and 'Martinenca'; or fruit color, as with 'Mallea' and 'Panachée'. The agronomic and economic importance of the cultivar in the consulted bibliography was the main criterion for selection of the reference cultivars. Table 1 shows the synonyms found in the germplasm bank and the reference cultivars selected. Establishment of the database with molecular profiles of reference genotypes will assist in management of the germplasm bank and aid in the screening of new accessions before their incorporation into the collection.
Examples for the most well-known cultivars are described below.

'Coll de Dama'. Risso (1826) described a cultivar known as Figue des Dames, and Simonet et al. (1945) used a similar name. Later, this cultivar was known as 'Col de Dame.' According to Condit (1955), Mazieres (1920) mentioned that this cultivar was distributed over southern France and Spain, where it originally came from. This would explain the high number of synonyms in this group among the fig genotypes prospected in Spain. However, the presence of different SSR profiles under the same denomination of 'Col de Dame' indicates also de presence of homonyms. According to Condit (1955), 'Col de Dame' is synonymous with 'Cuello de Dama Blanca', although in this study these names were associated with different genotypes (similarity of 0.73 ). Moreover, we have found some phenotypic differences among some of the cultivars that present the same SSR profile as 'Col de Dame' ('Coll de Dama Blanco', 'Coll de Dama Negre', and 'Coll de Dama Rosa'), due probably to microenvironmental factors or somatic mutations which probably have taken place throughout the history of fig cultivation, resulting in phenotypic intracultivar variability (Galderisi et al., 1999).

'LAMPAGA'. Both molecular results and phenotypic evaluation show that 'Lampaga' and 'Lampa Preta' are synonyms in our collection. According to Condit (1955), the Portuguese cultivar Lampo Preto, described by Bobone (1932), could be the same cultivar as Lampeira or Lampapas. The accession known in our collection as 'Pacueca' shows the same genetic profile as 'Lampaga' and 'Lampa Preta' based on SSRs, and 'Pacueca' is listed as a synonym for Lampaga within the Spanish parthenocarpic violet cultivars (Flores 1990). Because we do not have 'Lampeira' in our collection, we have preferred to maintain the name Lampaga for the selected cultivar of this group.

'Panachée'. The accession known in our collection as 'Calabacita R' is morphologically different from 'Calabacita', and this is corroborated by molecular analysis in this work. Morphological comparison (J.P. Roger, personal communication) indicates that Calabacita $\mathrm{R}$ is likely the cultivar known in France as Panachée, a very distinct cultivar with yellow- and green-striped fruit. Barron (1869) described it as an improved cultivar of Col de Signora Bianca, a synonym for Fraga according to Condit (1955). In fact, 'Fraga' presents the same genetic profile than 'Mallea' and 'Panachée' ('Calabacita R'). Then, 'Panachée' could have been derived from 'Fraga', probably by mutation, because they are clearly different at the morphological level but indistinguishable at the molecular level with the SSRs used in this work.

However, in other cases, the bibliographic data do not agree with the obtained results. Some examples are described below.

The unifera cultivars Jorba and Alacantina have been reported as synonyms (Estelrich, 1910). However, the results obtained show that 'Jorba' and 'Alacantina' present a similarity value of 0.72 . After comparing the morphological descriptions established by the different authors with the phenotype observed in the germplasm bank, we can conclude that the cultivar Alacantina in our collection is probably mislabeled.

Eisen (1901) identified 'Mission' as the Spanish 'Franciscana'. Condit (1955) described 'Franciscana' as a black fig cultivated in Malaga, Spain. It has been suggested (Condit, $1955)$ that the cultivars known as Negra and Breval introduced 
in California originated in Malaga and were identical to Franciscana. The SSR analysis of this study indicates that 'Mission' presents the same genetic profile as 'Negra', 'Negra Malaga', and 'Breval Malaga'. However, the genetic distance with 'Franciscana' (given the reference name of 'Roja Almohadin' in our collection) is very high because both accessions show a similarity index of 0.62 . Therefore, the cultivar Franciscana in our germplasm bank is probably not the same as the one identified by Eisen. This homonym could be due to an error in the labeling of the bank. To solve this controversy it would be necessary to find new specimens under this denomination and carry out new analyses.

Similarly, with the SSR markers used in this work it has not been possible to distinguish genotypes putatively derived from mutations from the original ones, such as 'Panachée' and 'Mallea'; 'Mission' and 'Albacor Negro'; 'Coll de Dama Negre', 'Coll de Dama Rosa', and 'Coll de Dama Blanca'; 'Brocalet' and 'Martinenca'; or 'Bermesca' and 'Calabacita', that can be easily distinguished phenotypically.

GENETIC RELATIONSHIPS BETWEEN Fig CUltivars. Among all possible dendrograms, the dendrogram with the highest cophenetic correlation coefficient (0.63) was chosen. Figure 1 represents the final dendrogram with the 104 reference genotypes after selecting one cultivar for each one of the 98 groups with the same genetic profile and six additional genotypes from five groups where two or three cultivars were selected because the morphological differences were clear (Table 1 ). The cultivars can be put into three main groups (A, B, and C) and five additional unique profiles (D). Accessions from the different geographic areas prospected are present in the three main groups, and, therefore, geographic origin is not the main criterion for the classification obtained. This could be explained due to the easy vegetative propagation of this species and its low edaphic and climatic requirements, which allow easy exchange of plant material among different geographical regions. However, certain subgroup classifications can be related to the production type, and some are supported by high bootstrap values. Examples include the unifera groups 'Hoñigal' and 9606 (bootstrap of 100\%); 'Panachée', 'Mallea', 'Blanca Foyos', 'Blanca R', 'Burjassot Blanca', and 'Boja o
Farta Belitres' (bootstrap of 99\%); 'Paratjal' and 'Mare de Deu' (bootstrap of 99\%); and the bifera groups 'De Baco', 'Angelina', and 'Blava' (bootstrap of 56\%) and 'Burreña', 'Mission', and 'Albacor' (bootstrap of 64\%). Moreover, the presence of the two caprifig cultivars (Tocal and San Joao Branco) clustered with parthenocarpic accessions could indicate a common origin derived from crosses between caprifigs and parthenocarpic accessions because in the presence of caprifigs, the second crop of common fig can be the result of pollination producing seeded figs. 
In addition to the main groups obtained in the dendrogram, five genetic profiles are different from the rest: 'Princesa', 'Martina', 'Smyrna', 9608, and 9614. The geographical origin of these genotypes could explain their differentiation from the rest of the accession conserved in the germplasm bank. 'Princesa' from Portugal is synonymous with 'Blanca', from Huelva in southwestern Spain. According to Gallesio (1817), the cultivar Blanca was present in Italy but not in Spain or France. In fact, this cultivar was not included in old publications of Spanish fig cultivars (Priego Jaramillo and Sanchiz, 1934). Nevertheless, in more recent Spanish publications (Flores, 1990), it appears as a good cultivar for dried figs, with good size fruit. The fact that the similarity value between this profile and the rest of the cultivars is low could be explained by accepting the hypothesis that this genotype comes from the Italian cultivar not introduced in Spain until the 20th century. Regarding 'Martina', this accession originated from a prospecting trip carried out in 1993 in the Balearic Islands. Studies based on the genetic diversity of wild fig tree populations in those islands show the low diversity and the strong differentiation of wild fig tree populations. This differentiation could be due to a possible establishment of Balearic fig populations before fig domestication (Khadari et al., 2005). Thus, some Balearic domesticated figs, such as 'Martina', could be derived from those ancient populations. Further studies with additional cultivars and wild material from the Balearic islands are needed to address this point. 'Smyrna' is a cultivar of Turkish origin, and this could explain its separation from the cultivars analyzed in this work which are mainly from Spain. Regarding 9608 and 9614 , they correspond to recent introductions in the germplasm bank from collections in Aragon (northern Spain).

The results obtained in this work indicate that SSRs are excellent codominant markers to optimize fig germplasm management, allowing distinction of synonyms and homonyms and studies of conserved diversity. This resulted in a reduction of the initial number of 209 accessions to 104 referenced cultivars. Further work with other fig germplasm collections is required to establish common criteria for cultivar naming and optimizing fig germplasm conservation worldwide.

\section{Literature Cited}

Barron, A.F. 1869. Col de Signora Bianca Panachée. Flor. Pomol. (Ser. 3) 2:145.

Berg, C.C. 2003. Flora Malesiana precursor for the treatment of Moraceae 1: the main subdivision of Ficus: the subgenera. Blumea 48:167-178.

Bobone, A. 1932. Contribuição para o estudo taxonómico da espécie Ficus carica L. PhD diss. Instituto Superior de Agronomia, Lisbon, Portugal.

Cabrita, L.F., U. Aksoy, S. Hepaksoy, and J.M. Leitao. 2001. Suitability of isozyme, RAPD and AFLP markers to assess genetic differences and relatedness among fig (Ficus carica L.) clones. Scientia Hort. 87:261-273.

Callen, D.F., A.D. Thompson, Y. Shen, H.A. Phillips, R.I. Richards, J.C. Mulley, and G.R. Sutherland. 1993. Incidence and origin of null alleles in the (AC)n microsatellite markers. Amer. J. Hum. Genet. 52:922-927.

Chessa, I., G. Nieddu, and P. Serra. 1998. Fig germplasm characterization using isozyme analysis. Acta Hort. 480:143-148.

Chessa, I. and G. Nieddu. 2005. Analysis of diversity in the fruit tree genetic resources from a Mediterranean island. Genet. Resources Crop Evol. 52:267-276.
Condit, I.J. 1955. Fig varieties: a monograph. Hilgardia 23:323-538. De Masi, L., D. Castaldo, G. Galano, P. Minasi, and B. Laratta. 2005. Genotyping of fig (Ficus carica L.) via RAPD markers. J. Sci. Food Agr. 85:2235-2242.

Eisen, G. 1901. The fig: its history, culture and curing, Vol. 9, p. 1-317. U.S. Dept. Agr. Div. Pomol. Bul. U.S. Government Printing Office, Washington, D.C.

Elisario, P.J., M.C. Neto, L.F. Cabrita, and J.M. Leitao. 1998. Isozyme and RAPDs characterization of a collection of fig tree (Ficus carica L.) traditional varieties. Acta Hort. 480:143-154.

Estelrich, P. 1910. La higuera y su cultivo en España. Librería Escolar, Palma de Mallorca, Spain.

Flores, D.A. 1990. La higuera. Mundi Prensa, Madrid, Spain.

Food and Agricultural Organization of the United Nations. 2005. FAOSTAT database. 29 June 2007. <http://faostat.fao.org/site/340/ default.aspx $>$.

Galderisi, U., M. Cipollaro, G. Di Bernardo, L. De Masi, G. Galano, and A. Cascino. 1999. Identification of the edible fig 'Bianco del Cilento' by random amplified polymorphic DNA analysis. HortScience 34:1263-1265.

Gallesio, G. 1817. Pomona Italiana ossia trattato degli alberi fruttiferi. Niccolo Capurro, Pisa, Italy.

Giraldo, E., M.A. Viruel, M. López-Corrales, and J.I. Hormaza. 2005. Characterisation and cross-species transferability of microsatellites in the common fig (Ficus carica L.). J. Hort. Sci. Biotechnol. 80:217-224.

Gupta, P.K. and R.K. Varshney. 2000. The development and use of microsatellite markers for genetic analysis and plant breeding with emphasis in bread wheat. Euphytica 113:163-185.

Janick, J. 2005. The origin of fruits, fruit growing, and fruit breeding. Plant Breed. Rev. 25:255-320.

International Plant Genetics Resources Institute and International Centre for Advanced Mediterranean Studies. 2003. Descriptors for fig. IPGRI and CIHEAM, Paris.

Khadari, B., P. Lashermes, and F. Kjellberg. 1995. RAPD fingerprints for identification and genetic characterization of fig (Ficus carica $\mathrm{L}$.) genotypes. J. Genet. Breed. 49:77-86.

Khadari, B., I. Hochu, S. Santoni, and F. Kjellberg. 2001. Identification and characterization of microsatellite loci in the common fig (Ficus carica L.) and representative species of the genus Ficus. Mol. Ecol. Notes 1:191-193.

Khadari, B., A. Oukabli, M. Ater, A. Mamouni, J.P. Roger, and F. Kjellberg. 2004. Molecular characterization of Moroccan fig germplasm using intersimple sequence repeat and simple sequence repeat markers to establish a reference collection. HortScience 40:29-32.

Khadari, B., C. Grout, S. Santoni, and F. Kjellberg. 2005. Contrasted genetic diversity and differentiation among Mediterranean populations of Ficus carica L.: a study using mtDNA RFLP. Genet. Resources Crop Evol. 52:97-109.

Kislev, M.E., A. Hartmann, and O. Bar-Yosef. 2006. Early domesticated fig in the Jordan Valley. Science 312:1372-1374.

Kjellberg, F., P.H. Gouyon, M. Ibrahim, M. Raymond, and G. Valdeyron. 1987. The stability of the symbiosis between dioecious figs and their pollinators: a study of Ficus carica L. and Blastophaga psenes L. Evolution (Int. J. Org. Evol.) 41:693-704.

de Mazieres, E. (1920) Le figuier, l'abricotier, le prunier et l'industrie des fruits seches. 89 pp. J.B. Ballière et Fils, Paris, France.

Nei, M. 1973. Analysis of gene diversity in subdivided populations. Proc. Natl. Acad. Sci. USA 70:3321-3323.

Nei, M. and W.H. Li. 1979. Mathematical model for studying genetic variation in terms of restriction endonucleases. Proc. Natl. Acad. Sci. USA 76:5269-5273.

Paetkau, D., W. Calvert, I. Stirling, and C. Strobeck. 1995. Microsatellite analysis of population structure in Canadian polar bears. Mol. Ecol. 4:347-354.

Papadopoulou, K., C. Ehaliotis, M. Tourna, P. Kastanis, I. Karydis, and G. Zervakis. 2002. Genetic relatedness among dioecious Ficus carica L. cultivars by random amplified polymorphic DNA analysis, 
and evaluation of agronomic and morphological characters. Genetics 114:183-194.

Priego Jaramillo, J.M. and S. Sanchiz. 1934. La higuera: su cultivo en España. Espasa-Calpe, Madrid, Spain.

Risso, A. 1826. Histoire naturelle des principales productions de l'Europe méridionale. Levrault, Paris.

Rosselló, J., J. Rallo, and J. Sacarès. 1996. Les figueres mallorquines. Fundació Illes Balears, Palma de Mallorca, Spain.

Sadder, M. and A. Ateyyeh. 2006. Molecular assessment of polymorphism among local Jordanian genotypes of the common fig (Ficus carica L.). Scientia Hort. 107:347-351.

Salhi-Hannachi, A., T. Mokhtar, Z. Salwa, H. Jihene, M. Messaoud, R. Abdelmajid, and M. Mohamed. 2004. Inter-simple sequence repeat fingerprints to assess genetic diversity in Tunisian fig (Ficus carica L.) germplasm. Genet. Resources Crop Evol. 51:269-275.

Salhi-Hannachi, A., C. Khaled, M. Messaoud, M. Mohamed, and T. Mokhtar. 2005. Comparative analysis of genetic diversity in two Tunisian collections of fig cultivars based on random amplified polymorphic DNA and inter simple sequence repeats fingerprints. Genet. Resources Crop Evol. 52:563-573.

Simonet, M., R. Chopinet, and J. Baccialone. 1945. Contribution à l'étude de quelques variétés de figuiers des Alpes-Maritimes et du Var. Rev. Bot. Appl. 25:44-75.
Storey, W.B. 1976. Fig Ficus carica (Moraceae), p. 205-208. In: N.W. Simmonds (ed.). Evolution of crop plants. Longman, Inc., New York. Van de Peer, Y. and R. De Wachter. 1994. TREECON for Windows: a software package for the construction and drawing of evolutionary trees for the Microsoft Windows environment. Comput. Appl. Biosci. 10:569-570.

Wagner, H.W. and K.M. Sefc. 1999. IDENTITY 1.0. Centre for Applied Genetics, University of Agricultural Sciences, Vienna, Austria.

Watson, L. and M.J. Dallwitz. 2004. The families of flowering plants: descriptions, illustrations, identification, and information retrieval. 29 June 2007. <http://delta-intkey.com/angio/www/index.htm>.

Wright, S. 1951. The genetical structure of populations. Ann. Eugen. 15:323-354.

Wünsch, A. and J.I. Hormaza. 2002. Cultivar identification and genetic fingerprinting of temperate fruit tree species using DNA markers. Euphytica 125:59-67.

Yeh, F.C. and T.J.B. Boyle. 1997. Population genetic analysis of codominant and dominant markers and quantitative traits. Belg. J. Bot. 129:57.

Zohary, D. and P. Spiegel-Roy. 1975. Beginnings of fruit growing in the old world. Science 187:319-327.

Zohary, D. and M. Hopf. 2000. Domestication of plants in the old world. 3rd ed. University Press, Oxford, England. 